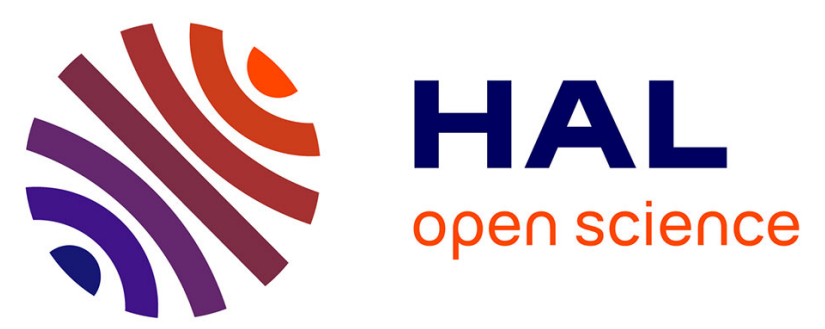

\title{
Combined process for removal of tetracycline antibiotic - Coupling pre-treatment with a nickel-modified graphite felt electrode and a biological treatment.
}

Daouia Belkheiri, Florence Fourcade, Florence Geneste, Didier Floner, Hamid Ait-Amar, Abdeltif Amrane

\section{To cite this version:}

Daouia Belkheiri, Florence Fourcade, Florence Geneste, Didier Floner, Hamid Aït-Amar, et al.. Combined process for removal of tetracycline antibiotic - Coupling pre-treatment with a nickel-modified graphite felt electrode and a biological treatment.. International Biodeterioration and Biodegradation, 2015, 103, 103, pp.147-153. 10.1016/j.ibiod.2015.02.032 . hal-01153056

HAL Id: hal-01153056

https://hal-univ-rennes1.archives-ouvertes.fr/hal-01153056

Submitted on 10 Sep 2015

HAL is a multi-disciplinary open access archive for the deposit and dissemination of scientific research documents, whether they are published or not. The documents may come from teaching and research institutions in France or abroad, or from public or private research centers.
L'archive ouverte pluridisciplinaire HAL, est destinée au dépôt et à la diffusion de documents scientifiques de niveau recherche, publiés ou non, émanant des établissements d'enseignement et de recherche français ou étrangers, des laboratoires publics ou privés. 


\section{Combined process for removal of tetracycline antibiotic - Coupling pre- treatment with a nickel-modified graphite felt electrode and a biological treatment}

Daouia Belkheiri ${ }^{1,4}$, Florence Fourcade ${ }^{1,2}$, Florence Geneste ${ }^{3,2}$, Didier Floner ${ }^{3,2}$, Hamid AïtAmar $^{4}$, Abdeltif Amrane ${ }^{1,2 *}$

${ }^{(1)}$ Université de Rennes 1, Ecole Nationale Supérieure de Chimie de Rennes, CNRS, UMR6226, Avenue du Général Leclerc, CS 50837, 35708 Rennes Cedex7, France.

${ }^{(2)}$ Université Européenne de Bretagne, 5 Boulevard Laënnec, 35000 Rennes, France

${ }^{(3)}$ Université Rennes 1, CNRS, UMR 6226, Equipe Matière Condensée et Systèmes Electroactifs, Campus de Beaulieu, 35042 Rennes Cedex, France

${ }^{(4)}$ Université des sciences et de la technologie Houari Boumediene, Laboratoire des Sciences du Génie des Procédés Industriels, B.P. 32, 16111 El-Alia, Alger

*Corresponding author: Phone: (+33) 22323 81 55; Fax: (+33) 2232381 20; abdeltif.amrane@univ-rennes1.fr 


\section{ABSTRACT}

Biodegradability improvement of tetracycline-containing solutions after an electrochemical pretreatment was examined. Cyclic voltammetry with a nickel electrode revealed a significant electrochemical activity of tetracycline, in both oxidation and reduction. Electrochemical treatment was therefore performed in a home-made flow cell using a nickel-modified graphite felt electrode as the working electrode. Optimal conditions, namely $100 \mathrm{mg}^{-1}$ initial tetracycline, above $0.45 \mathrm{~V}$ potential, and between 1 and $6 \mathrm{ml} \mathrm{min}^{-1}$ flow rate, led to a more than 99\% conversion yield of tetracycline in oxidation in alkaline conditions, after only a single pass through the percolation cell. However, total organic carbon (TOC) analyses revealed a low mineralization level, i.e., always below $31 \%$, underscoring the importance of a combined electrochemical and biological treatment. This was confirmed by the favorable trends of the COD/TOC ratio, decreasing from 2.7 to 1.9, and the average oxidation state, increasing from 0.044 to 1.15 , before and after oxidation pretreatment at $0.7 \mathrm{~V}$ and $3 \mathrm{ml} \mathrm{min}^{-1}$ flow rate. Electrolyzed solutions appeared biodegradable, since $\mathrm{BOD}_{5} / \mathrm{COD}$ increased from 0 to 0.46 for untreated and pretreated TC at $0.7 \mathrm{~V} / \mathrm{SCE}$. Biological treatment showed only biosorption for non-pretreated tetracycline, while after 11.5 days of culture, the mineralization of solutions electrolyzed in oxidation was $54 \%$, leading to a $69 \%$ overall TOC decrease during the combined process.

Keywords:

Tetracycline

Carbon felt anode

Combined processes 
Biodegradability

\section{Introduction}

Tetracycline (TC) represents an important group of polyketide antibiotics. It is commonly used in human and veterinary medicine, in aquaculture, and as an additive to animal feeds, and it can also inhibit fungal growth in fruit trees. It is active against a wide range of Gram-positive and Gram-negative bacteria (Chopra and Roberts, 2001). It is widely used in European countries; in Germany, for instance, in 2007 , over $17,000 \mathrm{~kg}$ of tetracycline were consumed by livestock as antimicrobial substances applied to pigs (Merle et al., 2012).

Only small portions of antibiotics administered to treated species are metabolized or absorbed in the body; most of the unchanged form of the drug is eliminated in faeces and urine (Arikan et al., 2006). Between 30 and 90\% is excreted unchanged into the waste system (Hirsch et al., 1999). The presence of low levels of antibiotics and their transformation products in the environment could have adverse effects, such as bacterial resistance and disruption of key cycles critical to aquatic ecology or crop and animal production (Kummerer, 2004; Costanzo et al., 2005; Crane et al., 2006).

Due to their refractory characteristics as well as their antibacterial effects, biological methods are not efficient for antibiotic removal (Reyes et al., 2006). Indeed, biological removal using activated sludge showed only adsorption onto the solid phase without degradation (Prado et al., 2009).

Chemical oxidation could efficiently destroy antibiotics and overcome most of the limitations encountered during other conventional processes; especially the advanced oxidation 
processes (AOP), which constitute the most important and widely documented group (Chiron et al., 2000; Oppenländer, 2003; Badawy et al., 2006). The AOP can be divided into three categories: photochemical processes, ozonation combined with UV irradiation and/or hydrogen peroxide $\left(\mathrm{H}_{2} \mathrm{O}_{2}\right)$, and in-situ generation of free radicals ${ }^{\bullet} \mathrm{OH}$ by other technologies. They are efficient but can be costly (Mohajerani et al., 2009).

Electrochemical processes also showed a remarkable ability to remove recalcitrant organic contaminants such as antibiotics (Walsh and Mills, 1993). An electrochemical reaction is based on a heterogeneous electronic transfer, and the mean reactants are electrons. Weichgrebe et al. (2004) studied the biocide effect during electrochemical oxidation of tetracycline in water at an initial concentration of $1 \mathrm{~g} \mathrm{l}^{-1}$. Zhang et al. (2009) investigated the effect of various operating conditions on the electro-oxidation of tetracycline with a $\mathrm{Ti} / \mathrm{RuO}_{2}$ anode; similar studies used gold diamond and platinum anodes (Weichgrebe et al., 2004; Kraft, 2007; Masawat and Slater, 2007; Zhang et al., 2009). Electro-oxidation has appeared efficient for tetracycline degradation but has been carried out mostly on onerous anode materials.

For electroactive target compounds, oxidation or reduction can be carried out for their removal. Direct electrochemical processes are relevant in the case of a specific pollutant owing to the targeted selectivity, and therefore would be appropriate to treat low volumes of highly concentrated pollutants.

Reducing the antibacterial activity of a tetracycline solution does not necessarily require its complete mineralization. All that is needed is to break down the initial tetracycline molecules (Vedenyapina et al., 2008). Effluent mineralization can subsequently be completed during biological treatment; the potential advantages of the strategy of combining physicochemical and 
biological processes to treat contaminants in wastewater have previously been described (Scott and Ollis, 1995, 1997; Pulgarin et al., 1999; Farré, et al., 2007).

Biodegradability improvement of solutions of 2,4-dichlorophenoxyacetic acid after a direct electrochemical oxidation in a homemade flow-cell involving a bare graphite felt electrode has been shown (Fontmorin et al., 2012), and complete mineralization (97\%) of a pesticide, phosmet, was obtained by coupling an electrochemical reduction by means of the same electrolysis system and an activated sludge culture (Alonso-Salles et al., 2010). Regarding the target compound, tetracycline, a significant electrochemical activity was shown by cyclic voltammetry with a vitreous carbon electrode, and hence electrochemical treatment was performed in a home-made flow cell with a bare graphite felt electrode. Biodegradability, based on the $\mathrm{BOD}_{5}$ (five-day biochemical oxygen demand) to COD (chemical oxygen demand) ratio, increased with the oxidation potential until reaching 0.39 , namely a biodegradable solution for 1.6 V/SCE, while no biodegradability improvement was observed after electrolysis in reduction, even though the resulting solution was not toxic for activated sludge. In addition, TOC analyses of the electrolyzed solution revealed that the level of mineralization remained low indicating the potential of a combined electrochemical and biological treatment (Belkheiri et al., 2011).

In order to improve the efficiency of the electrolysis pretreatment, especially through attempts to reduce the working potential, modification of the graphite felt electrode by nickel electrodeposition has been considered (Chamoulaud et al., 2001). Indeed, nickel oxidation on the electrode leads to the formation of a nickel oxyhydroxide, $\mathrm{NiOOH}$, known to catalyze the oxidation of some organic molecules (Fleischmann et al., 1971; Vértes and Horányi, 1974). The purpose of this study was therefore to examine the electrochemical behavior of tetracycline with 
an electrode modified by nickel electrodeposition and to determine if this improved the biodegradability of the tetracycline.

\section{Materials and methods}

\subsection{Chemicals and reagents}

Tetracycline hydrochloride (<96\% HPLC-grade) is displayed in Fig. 1 and was obtained from Sigma Aldrich (Saint-Quentin Fallavier, France). Acetonitrile (ACN) was HPLC grade from Fisher Scientific (Illkirch, France), and formic acid (LC-MS grade, 98\%) was purchased from J.T. Baker (Deventer, Holland). Standards were prepared with ultra-pure water (Purelab Options- Q7/15, Elga, 18.2 M $\Omega \cdot \mathrm{cm}^{-1}$ ). All other reagents were of analytical grade.

\subsection{Materials for the electrochemical pre-treatment}

Electrochemical pre-treatment, in a continuous system, was performed in a home-made flow cell (Fig. 2a). The working electrode was obtained by nickel electrodeposition on the surface of the carbon felt. The electrode was made in the laboratory (by Floner and co-workers) at room temperature in an electrochemical cell formed by an open rectangular tank containing 1 $\mathrm{L}$ of the electrolyte solution (sodium sulfate and boric acid, $0.25 \mathrm{M}$ each). The mechanism of nickel electrodeposition in acidic medium can be summarized in its simplest form by the

reaction: $\mathrm{Ni}_{\mathrm{aq}^{2+}}+2 \mathrm{e}^{-} \rightarrow \mathrm{Ni}$ (Floner and Moinet, 2004; Floner and Geneste, 2007). The electrode was uniformly covered by nickel (around $1 \mu \mathrm{m}$ thickness). There were no obvious defects and 
cracks of the coating layer found on the electrode surface and it had a smooth surface, as shown in the SEM micrograph obtained with a JEOL 6301F (9 kV) microscope (Fig. 2b). Its specific area, measured by the BET method, was $1 \mathrm{~m}^{2} \mathrm{~g}^{-1}$ and its density was about $0.37 \mathrm{~g} \mathrm{~cm}^{-3}$, with a specific surface area related to the volume of $3700 \mathrm{~cm}^{2} \mathrm{~cm}^{-3}$. The working electrode was $0.3 \mathrm{~cm}$ high and $4 \mathrm{~cm}$ in diameter, leading to a volume of $3.768 \mathrm{~cm}^{3}$, with a total surface of $1.39 \mathrm{~m}^{2}$. The electrode was separated from the two interconnected stainless steel counter-electrode compartments by cationic exchange membranes (Ionac 3470 - Lanxess SAS, Courbevoie, France). A good homogeneity of the potential distribution in the three-dimensional working electrode was obtained when the felt was located between two counter-electrodes (Moinet, 1994). The reference electrode (SCE) was positioned in the middle of the felt. The potential control was performed using an e-daq potentiostat linked to an e-corder 401 converter (AD Instruments Pty Ltd., Castle Hill, Australia). The tetracycline concentration (TC) was $100 \mathrm{mg} \mathrm{l}^{-1}$. The supporting electrolyte used was $0.1 \mathrm{M} \mathrm{Na}_{2} \mathrm{SO}_{4}$. The TC solution percolated the porous electrode at a constant flow rate monitored by a Gilson minipuls 2 peristaltic pump (Middleton, WI, USA).

\subsection{Analysis}

\subsubsection{Electrochemical analysis}

Electrochemical analysis of tetracycline was performed using a conventional three electrode-cell with a nickel electrode $\left(20 \mathrm{~mm}^{2}\right)$ as working electrode and a platinum wire as counter electrode. All the electrode potentials were measured with respect to a saturated calomel electrode (SCE) located near the working electrode. 
Experiments were performed at ambient temperature under a nitrogen atmosphere. Voltammograms were obtained by cyclic voltammetry $\left(100 \mathrm{mVs}^{-1}\right)$ using an e-daq potenstiostat linked to an e-corder 401 converter. The sense of the potential (E) sweeping is indicated by an arrow.

\subsubsection{UPLC}

The residual tetracycline concentration was determined by a UPLC (ultra-high-pressure liquid chromatography) system involving a Waters Acquity UPLC ${ }^{\circledR}$ H-Class gradient pump and a PDA (photo diode array) UV detector. $\mathrm{A}_{18} \mathrm{BEH}$ (bridged ethylene hybrid) column, $1.7 \mu \mathrm{m}$ $(2.1 \times 50 \mathrm{~mm}$ ) was used. A gradient elution was carried out with $0.1 \%$ formic acid in ultra-pure water (solvent A) and acetonitrile (solvent B) as follows: 90/10\% from 0 to $1 \mathrm{~min}$; from 1 to 4.5 min elution was linearly modified from $90 / 10$ to $2 / 98 \%$, maintained at $2 / 98 \%$ from 4.5 to $5 \mathrm{~min}$; from 5 to 5.5 min elution was linearly modified from $2 / 98$ to $90 / 10 \%$, where it was maintained from 5.5 to 10 min for solvents A and B, respectively.

The flow rate was $0.5 \mathrm{ml}$. Tetracycline was detected at $360 \mathrm{~nm}$. More detailed information on the UPLC determination can be found in a previous paper (Belkheiri et al., 2011).

\subsubsection{Total organic carbon (TOC) and total nitrogen measurements}

Total organic carbon and total nitrogen were measured by means of a Schimadzu total organic analyzer (TOC- $\left.\mathrm{V}_{\mathrm{CPH}} \mathrm{TOC}-\mathrm{V}_{\mathrm{CPN}} / \mathrm{TOC}-\mathrm{V}_{\mathrm{WP}}\right) . \mathrm{HCl}(2 \mathrm{~N})$ and $\mathrm{H}_{3} \mathrm{PO}_{4}(25 \%)$ were considered for $\mathrm{CO}_{2}$ and $\mathrm{NO}$ production. Organic carbon compounds were combusted and converted to $\mathrm{CO}_{2}$, which was detected by a non-dispersive infrared detector (NDIR). Dissolved nitrogen compounds were combusted and converted to NO, which was then mixed with ozone 
chemiluminescence for detection by a photomultiplier. Analyses were run in triplicate.

\subsubsection{Chemical oxygen demand (COD) measurements}

Chemical oxygen demand (COD) was measured by means of a Test Nanocolor ${ }^{\circledR}$ CSB 40 and 160 from Macherey-Nagel (Düren, Germany). The amount of oxygen required for the oxidation of the organic and mineral matter at $148^{\circ} \mathrm{C}$ for $2 \mathrm{~h}$ was quantified after oxidation with $\mathrm{K}_{2} \mathrm{Cr}_{2} \mathrm{O}_{7}$ at acidic $\mathrm{pH}$ and with heating. Analyses were triplicated.

\subsubsection{Toxicity}

Toxicity was measured by means of the Microtox test (using a Microtox 500 analyser, which is a laboratory-based temperature-controlled photometer $\left[15-27^{\circ} \mathrm{C}\right]$ that maintains the luminescent bacteria reagent and test samples at the appropriate temperature. This selfcalibrating instrument measures the light production from a luminescent marine bacterial strain, Vibrio fischeri NRRL B-11177 (standard ISO 11348-3). The sample toxicity is determined by measuring the effective concentration at which $50 \%$ of the light is lost due to compound toxicity (EC50) (Sarria et al., 2002).

\subsubsection{Biological oxygen demand (BOD5) measurements (Delzer and McKenzie 2003)}

Biodegradability was deduced from $\mathrm{BOD}_{5}$ measurements, carried out in an Oxitop IS6 (WTW, Alès, France). Activated sludge from a wastewater treatment plant was used to inoculate the flasks; the initial microbial concentration was $0.5 \mathrm{~g} \mathrm{l}^{-1}$.

$1 \mathrm{ml}$ of a mineral solution and $2.5 \mathrm{ml}$ of a phosphate solution were added to $164 \mathrm{ml}$ of sample. The composition of the mineral solution was (in $\mathrm{g} \mathrm{l}^{-1}$ ): $\mathrm{MgSO}_{4} .7 \mathrm{H}_{2} \mathrm{O}, 22.5 ; \mathrm{CaCl}_{2}, 27.5$; 
$\mathrm{FeCl}_{3}, 0.15 ; \mathrm{NH}_{4} \mathrm{Cl}, 2.0$; and that of the phosphate solution was $\left(\mathrm{g}^{-1}\right)$ : $\mathrm{Na}_{2} \mathrm{HPO}_{4}, 6.80 ; \mathrm{KH}_{2} \mathrm{PO}_{4}$, 2.80 .

The $\mathrm{BOD}_{5}$ value was initially estimated based on the COD value experimentally measured by means of a Nanocolor test CSB 160 (Macherey-Nagel, Düren, Germany); BOD $5=$ $\mathrm{COD} / 1.46$. The range of expected $\mathrm{BOD}_{5}$ values was then deduced and hence led to the volumes of sample of activated sludge solution and of nitrification inhibitor $\left(0.5 \mathrm{ml}\right.$ of $10 \mathrm{mg}^{-1}$ solution of $N$-Allylthiourea), which have to be added in the shake flask of the Oxitop apparatus.

Similar protocol was applied for the control flask except that it was replaced by a solution of easily biodegradable compounds, namely glutamic acid $\left(150 \mathrm{mg} \mathrm{l}^{-1}\right)$ and glucose $\left(150 \mathrm{mg} \mathrm{l}^{-1}\right)$. Before use, $\mathrm{KOH}$ was added to achieve neutral $\mathrm{pH}(7.0 \pm 0.2)$. A similar protocol was also considered for the blank solution, for which the sample was replaced by water to deduce the biological oxygen demand corresponding to the endogenous respiration. All BOD 5 measurements were duplicated.

\subsection{Biological treatment}

After only one pass through the electrochemical flow-cell, the effluent was collected for subsequent biological treatment. The biological treatment was carried out in aerobic conditions, using activated sludge purchased from a local wastewater treatment plant (Beaurade, Rennes, France). Prior to the experiment, activated sludge was washed four times with tap water and once with distilled water. After each washing, activated sludge was centrifuged at $3000 \mathrm{rpm}$ for five minutes (Jouan, Thermo Fisher Scientific, Saint Herblain, France). The supernatant was then separated from the sludge to dispose of any residual carbon or mineral source. 
Duplicate experiments were carried out in 600-ml Erlenmeyer flasks containing $450 \mathrm{ml}$ of medium. Each sample was run in triplicate, stirred at $200 \mathrm{rpm}$, and kept at $25^{\circ} \mathrm{C}$. The following mineral basis was used for each sample:

-1 $\mathrm{ml}$ of the following solution $\left(\mathrm{g} \mathrm{l}^{-1}\right): \mathrm{KH}_{2} \mathrm{PO}_{4}, 8.5 ; \mathrm{K}_{2} \mathrm{HPO}_{4}, 20.8 ; \mathrm{Na}_{2} \mathrm{HPO}_{4} .2 \mathrm{H}_{2} \mathrm{O}, 33.4$.

- $0.4 \mathrm{ml}$ of the following solutions $\left(\mathrm{g}^{-1}\right)$ : $\mathrm{CaCl}_{2}, 27.6 ; \mathrm{MgSO}_{4} .7 \mathrm{H}_{2} \mathrm{O}, 22.6 ; \mathrm{FeCl}_{3} .6 \mathrm{H}_{2} \mathrm{O}, 0.26$.

-- $1 \mathrm{ml}$ of a trace elements solution containing $\left(\mathrm{g} \mathrm{l}^{-1}\right): \mathrm{CuSO}_{4} .7 \mathrm{H}_{2} \mathrm{O}, 1.36 ; \mathrm{ZnSO}_{4} .5 \mathrm{H}_{2} \mathrm{O}, 0.25$; $\mathrm{NiSO}_{4} \cdot 6 \mathrm{H}_{2} \mathrm{O}, 0.11 ; \mathrm{MnSO}_{4} \cdot \mathrm{H}_{2} \mathrm{O}, 1.01 ; \mathrm{H}_{3} \mathrm{BO}_{3}, 0.10$; and $\mathrm{H}_{2} \mathrm{SO}_{4}, 1 \mathrm{ml} \mathrm{l}{ }^{-1}$.

The culture medium also contained $\mathrm{NH}_{4} \mathrm{Cl}, 75 \mathrm{mg} \mathrm{l}^{-1}$, as nitrogen source; as well as either the tetracycline concentration at $100 \mathrm{mg}^{-1}$, or a solution of $100 \mathrm{mg}^{-1} \mathrm{TC}$ electrolyzed in oxidation at $-0.7 \mathrm{~V}$ at a flow rate of $3 \mathrm{ml} \mathrm{min}^{-1}$. A primary carbon source, glucose $100 \mathrm{mg} \mathrm{l}^{-1}$, was also added as a carbon co-substrate. The $\mathrm{pH}$ of each sample was then adjusted to $7.0 \pm 0.2$ with 1 mol $1^{-1} \mathrm{NaOH}$.

Samples $(5 \mathrm{ml})$ were taken every 2 or 3 days and filtered on $0.45 \mu \mathrm{m}$. Measurements of pH were carried out using a Hanna pH meter with a combined micro-electrode probe (Thermo Spectronic, Rochester, NY). Samples were then diluted for TOC and TC measurements.

\section{Results and discussion}

\subsection{Electrochemical behaviour of tetracycline}

The electroactivity of tetracycline $\left(1 \mathrm{~g} \mathrm{l}^{-1}\right)$ was examined in oxidation in alkaline medium $\left(\mathrm{NaOH} 0.1 \mathrm{~mol}^{-1}\right)$ and in reduction in acidic medium (phosphate buffer $0.25 \mathrm{~mol}^{-1}$ ) by cyclic voltammetry on a nickel electrode. Alkaline conditions were established for oxidation, since it is 
well-known that under these conditions, oxyhydroxide NiOOHs are formed, leading to electrocatalysis of organic compounds, mainly alcohols (Fleischmann et al., 1971; Vértes and Horányi, 1974). Reduction tests were carried out in an acidic medium ( $\mathrm{pH}=2.2$ phosphate buffer $\left.0.25 \mathrm{~mol} \mathrm{l}^{-1}\right)$, since it favors the electrocatalytic hydrogenation $(\mathrm{ECH})$ of compounds (Martel et al., 1997; Vilar et al., 2010).

\subsubsection{Oxidation tests}

Voltammograms obtained in the presence of only $\mathrm{NaOH}$ display a quasi-reversible system around $0.38 \mathrm{~V}_{\mathrm{SCE}}$ (Fig.3 a). This signal has to be related to the reversible couple nickel hydroxide / nickel oxyhydroxide $\left(\mathrm{Ni}(\mathrm{OH})_{2} / \mathrm{NiOOH}\right)$. This couple is known to appear above $\mathrm{pH}$ 12 (Hahn et al., 1987).

$\mathrm{Ni}(\mathrm{OH})_{2} \rightleftharpoons \mathrm{NiOOH}+\mathrm{H}^{+}+e^{-}$

The voltammogram of the target compound showed an increase of the anodic signal of the quasireversible system, showing that in alkaline conditions tetracycline can be oxized on nickel. It seems that the formation of $\mathrm{NiOOH}$ on the electrode allows the oxidation of tetracycline, probably by a reaction with the alcohols groups of the molecule. Interestingly, the oxidation potential (around $0.5 \mathrm{~V}_{\mathrm{SCE}}$ ) was significantly lower than those observed on the graphite-felt electrode (1 V/SCE - (Belkheiri et al. 2011)), due to the catalytic properties of nickel.

Owing to the high concentration of tetracycline that can be achieved in some effluents, experiments were also carried out for tetracycline concentrations of $0.1 \mathrm{~g} \mathrm{l}^{-1}$ (not shown). The electrochemical oxidation of tetracycline was still observed at this concentration, underscoring the importance of the electrochemical process on nickel.

\subsubsection{Reduction tests}


The electrochemical behavior of tetracycline in reduction in buffered acidic medium at pH 2.2 is displayed in Fig.3b. The presence of tetracycline induces a slight anodic shift of the reduction of water in dihydrogen. The reduction of water on the nickel electrode in acidic medium proceeds as follows (Martel et al., 1997; Vilar et al., 2010):

$\mathrm{Ni}+\mathrm{H}_{3} \mathrm{O}^{+}+e^{-} \rightarrow \mathrm{NiH}+\mathrm{H}_{2} \mathrm{O}$

$2 \mathrm{NiH} \rightarrow \mathrm{H}_{2}+2 \mathrm{Ni}$

The anodic shift of the electrochemical signal shows that adsorbed dihydrogen $(\mathrm{NiH})$ is involved in a reaction with adsorbed tetracycline, favouring reaction (1). Thus, cyclic voltammetry analyses seem to show an electrocatalytic hydrogenation reaction of tetracycline on the nickel electrode, which should be confirmed by electrolysis.

\subsection{TC electrolysis}

Since cyclic voltammetry showed the feasibility of an electrochemical pre-treatment, electrolysis of tetracycline were studied at $0.1 \mathrm{~g} \mathrm{l}^{-1}$ in both oxidation and reduction.

\subsubsection{Reduction}

Cathodic reduction was performed in phosphate buffered acidic medium $(\mathrm{pH} \mathrm{2.1)}$ at $1 \mathrm{ml}$ $\min ^{-1}$ at different potentials (Table 1). The TC concentration was followed by HPLC. The results show that TC removal yield increased for increasing negative potentials. However, even at -1.0 $\mathrm{V}$, the residual amount of TC remained high $\left(17.5 \mathrm{mg} \mathrm{l}^{-1}-\right.$ Table 1$)$, whereas the hydrogen evolution rate becomes more significant with increasing polarization potential. Since more cathodic potentials should even more enhance reaction (2), we considered the oxidation of tetracycline rather than the reduction as a possible pretreatment. 


\subsubsection{Oxidation}

Oxidation was examined for a TC concentration of $100 \mathrm{mg} \mathrm{l}^{-1}$, in alkaline medium (pH 13) at $1 \mathrm{ml} \mathrm{min}{ }^{-1}$.

Tetracycline concentration degradation appeared almost negligible for potentials below $0.4 \mathrm{~V}$ (Table 1). These results confirmed cyclic voltammetry analyses, since the oxidation signal became noticeable from about $0.4 \mathrm{~V}$, corresponding to the formation of nickel oxyhydroxides (NiOOH). Above this potential, an almost total TC removal was always observed, showing the efficiency of the catalytic system. To optimize the electrochemical process, the flow rate effect was also examined at $0.7 \mathrm{~V}$, corresponding to a total TC removal for a flow rate of $1 \mathrm{ml} \mathrm{min}{ }^{-1}$ (Table 1). Interestingly, for all the studied flow rates, total TC degradation was achieved, as confirmed by TC determination by HPLC. However, mineralization yield decreased for increasing flow rates (Table 2) and was almost stable (around 15\%) from $3.5 \mathrm{ml} \mathrm{min}^{-1}$. This can be explained by further oxidation of byproducts occurring at low flow rates, leading to higher degradation yields.

Even if tetracycline was completely degraded after oxidation, the mineralization level remained low; it increased from $13.3 \%$ for $6 \mathrm{ml} \mathrm{min}^{-1}$ to $31 \%$ for $1 \mathrm{ml} \mathrm{min}{ }^{-1}$ (Table 2). It should be noted that the electrochemical process was carried out in order to selectively degrade the target compound to obtain byproducts that were expected to be biologically assimilated by microorganisms from activated sludge. Therefore, such electrochemical pretreatment seems to be relevant for the tetracycline molecule, owing to the important amount of residual organic carbon available for a subsequent biological treatment. 


\subsection{COD measurements}

Generally COD decrease involves a chemical oxidation of the target molecule and therefore a modification of its chemical structure that could lead to a decrease of its toxicity, while low mineralization is desired to ensure sufficient residual organic carbon for a subsequent biological treatment (Bandara et al., 1997; Sarria et al., 2003; Oller et al., 2007). Consequently, a favorable trend is a decrease of the COD/TOC ratio (Chebli et al., 2010) or an increase of the average oxidation state (AOS) (Pulgarin et al., 1999; Sarria et al., 2002):

$$
A O S={ }^{*}(T O C-C O D) / T O C
$$

with TOC and COD expressed in molar carbon per liter and molar oxygen per liter, respectively.

The TOC and COD values for the untreated tetracycline were 55.5 and $145 \mathrm{mg} \mathrm{l}^{-1}$. From this, mineralization and oxidation yields varied in the range 9.7 to $33.5 \%$ and 19.3 to $31.7 \%$ for flow rates between 1 and $5 \mathrm{ml} \mathrm{min}^{-1}$, respectively (Table 3). Hence, the COD to TOC ratio increased only slightly from 2.6 for the untreated tetracycline to 3.2 for a $1 \mathrm{ml} \mathrm{min}^{-1}$ flow rate, while it decreased significantly for 3 and $5 \mathrm{ml} \mathrm{min}^{-1}$ (Table 3), thus showing a favorable trend. Regarding AOS, it also decreased for a $1 \mathrm{ml} \mathrm{min}^{-1}$ flow rate, while it followed a favorable trend for higher flow rates, 3 and $5 \mathrm{ml} \mathrm{min}{ }^{-1}$ (Table 3).The oxidation on nickel electrodes at flow rates above $1 \mathrm{ml} \mathrm{min}{ }^{-1}$ therefore seemed advantageous for electrolysis prior to a biological treatment.

\subsection{Toxicity and biodegradability}

Pure tetracycline at a concentration of $100 \mathrm{mg} \mathrm{l}^{-1}$ was toxic for activated sludge, since the toxicity threshold is $18 \mathrm{mg} \mathrm{l}^{-1}$ (Prado et al., 2010); this was illustrated by the $\mathrm{BOD}_{5}$ value, which 
was below that of the blank sample, and was confirmed by the Microtox test, since the EC50 value was $13 \%$ (corresponding to $50 \%$ cell death, Vibrio fischeri).

Toxicity decreased after electrolysis since an $\mathrm{EC}_{50}$ value of $52 \%$ was obtained for a $3 \mathrm{ml}$ $\min ^{-1}$ flow rate. Biodegradability was checked by determination of the $\mathrm{BOD}_{5}$ to $\mathrm{COD}$ ratio, since for values above 0.4, the effluent can be considered as biodegradable (Pulgarin et al., 1999; Sarria et al., 2002). The favorable trend was confirmed, since after electrolysis the $\mathrm{BOD}_{5}$ to COD ratio was above the biodegradability threshold for 1 and $3 \mathrm{ml} \mathrm{min}^{-1}$ and close to the threshold for $5 \mathrm{ml} \mathrm{min}{ }^{-1}$ (Table 3), showing the biodegradability of the byproducts from TC oxidation.

\subsection{Biological treatment}

In the absence of electrochemical pretreatment, the initial decrease observed for tetracycline (Fig.4) should be related to biosorption on activated sludge. Indeed, the adsorbed amount corresponded to $37.5 \%$ of the initial amount (not shown), and this was correlated with the TOC decrease (35.5\%; Fig.4). This high amount of adsorbed TC was in agreement with previous findings, i.e., $39.8 \% \mathrm{TC}$ and $41 \%$ TOC biosorption on activated sludge for Yahiat et al. (2011), as well as with the trend observed by Prado et al. (2009) who showed that adsorption is the most likely fate for tetracycline in a biological system. Throughout culturing, the TC concentration remained constant within the limits of experimental error (Fig.4), in agreement with the absence of TC biodegradability (Prado et al., 2009) and its potential toxicity for activated sludge remained, since TC concentration remained always above the threshold level of $18 \mathrm{mg} \mathrm{l}^{-1}$ (Prado et al., 2010). Owing to TC toxicity, the weak TOC increase observed from about $50 \mathrm{~h}$ of culture may be attributed to cell lysis. 
The TOC decreased during biological treatment with an electrolyzed TC solution. This showed a continuous decrease of the residual TOC amount over the period of culture (Fig.4), which obviously cannot be attributed to the biosorption of byproducts which is a rapid mechanism which take only a few hours (Prado et al., 2009). It should be remembered that TC was completely oxidized after only one pass through the percolation cell, so no residual TC was expected after biological treatment. Decrease in TOC was observed until about 11.5 days of culture, leading to about $54 \%$ mineralization; then the TOC level remained nearly constant until the end of culture (Fig.4). From this the overall TOC decrease during the combined process was $69 \%$, corresponding to the abatement from the initial TOC value, before electrolysis pretreatment (55.5 $\mathrm{mg} \mathrm{l}^{-1}$ for untreated TC - Table 3) to the final value observed at the end of the activated sludge culture (close to $17 \mathrm{mg}^{-1}-$ Figure 4 ). The significant residual TOC amount showed that some degradation byproducts in the oxidized effluent samples could not be assimilated by microorganisms even after 18 days of culture. An incomplete mineralization was also previously observed during the coupling of electrochemical pretreatment on a non-modified graphite-felt electrode and a biological treatment for the degradation of a pesticide, 2,4-dichlorophenoxyacetic acid (Fontmorin et al., 2013). However, the proposed combined process appeared especially promising considering the inefficiency of a widely used AOP, photocatalysis, to improve the biodegradability of TC solutions, owing to the presence of non-biodegradable byproducts (Yahiat et al., 2011, 20121; Maroga Mboula et al., 2012). To continue this study, research is in progress in the laboratory to examine the relevance of the proposed combined process to treat synthetic solutions of a widely used macrolide antibiotic, tylosin.

\section{Conclusions}


The electroactivity of tetracycline $\left(1 \mathrm{~g} \mathrm{l}^{-1}\right)$ was examined under oxidation conditions in alkaline medium $\left(\mathrm{NaOH} 0.1 \mathrm{~mol} \mathrm{l}^{-1}\right)$ and under reduction in an acidic medium (phosphate buffer $0.25 \mathrm{~mol}^{-1}$ ) using cyclic voltammetry with a nickel electrodeposition-modified graphite felt electrode. To our knowledge, such an electrode has never been studied for TC degradation. Tetracycline can be oxidized in alkaline conditions on nickel at an oxidation potential of only 0.5 $\mathrm{V}_{\mathrm{SCE}}$, which is significantly lower than possible with a graphite-felt electrode (1 V/SCE (Belkheiri et al., 2011)). An electrocatalytic hydrogenation reaction of tetracycline on the nickel electrode was also shown; however, that reaction remained limited even at a potential of $-1.0 \mathrm{~V}$. An oxidation pretreatment was therefore considered.

For $0.7 \mathrm{~V}$, the COD on the TOC followed a favorable trend since it decreased significantly for 3 and $5 \mathrm{ml} \mathrm{min}{ }^{-1}$; a similar trend was also recorded for AOS. The favorable trend was confirmed since toxicity decreased after electrolysis; an $\mathrm{EC}_{50}$ value of $52 \%$ was obtained for $3 \mathrm{ml} \mathrm{min}^{-1}$ while it was initially $13 \%$, and the $\mathrm{BOD}_{5}$ to $\mathrm{COD}$ ratio was above the biodegradability threshold for 1 and $3 \mathrm{ml} \mathrm{min}^{-1}$ and close to this threshold for $5 \mathrm{ml} \mathrm{min} \mathrm{m}^{-1}$. Confirming these results, activated sludge culture led to $54 \%$ mineralization of solutions electrolyzed in oxidation, leading to a $69 \%$ overall TOC decrease during the combined process. 


\section{References}

Alonso-Salles, N., Fourcade, F., Geneste, F., Floner, D., Amrane, A., 2010. Relevance of an electrochemical process prior to a biological treatment for the removal of an organophosphorous pesticide, phosmet. Journal of Hazardous Materials 181, 617-623.

Arikan, O.A., Sikora, L.J., Mulbry, W., Khan, S.U., Rice, C., Foster, G.D., 2006. The fate and effect of oxytetracycline during the anaerobic digestion of manure from therapeutically treated calves. Process Biochem. 41, 1637-1643.

Badawy, M.I., Ghaly, M.Y., Gad-Allah, T.A., 2006. Advanced oxidation processes for the removal of organo phosphorus pesticides from wastewater. Desalination 194, 166-175.

Bandara, J., Pulgarin, C., Peringer, P., Kiwi, J., 1997. Chemical (photo-activated) coupled biological homogeneous degradation of p-nitro-o-toluene-sulfonic acid in a flow reactor. Journal of Photochemistry and Photobiology A: chemistry 111, 253-263.

Belkheiri, D., Fourcade, F., Geneste, F., Floner, D., Aït-Amar, H., Amrane, A., 2011. Feasibility of an electrochemical pre-treatment prior to a biological treatment for tetracycline removal. Separation and Purification Technology 83, 151-156.

Chamoulaud, G., Floner, D., Moinet, C., Lamy, C., Belgsir, E.M., 2001. Biomass conversion II: simultaneous electrosyntheses of furoic acid and furfuryl alcohol on modified graphite felt electrodes. Electrochimica Acta 46, 2757-2760.

Chebli, D., Fourcade, F., Brosillon, S., Nacef, S., Amrane, A., 2010. Supported photocatalysis as a pre-treatment prior to biological degradation for the removal of some dyes from aqueous solutions; Acid Red 183, Biebrich Scarlet, Methyl Red Sodium Salt, Orange II. Journal of Chemical Technology and Biotechnology 85, 555-563. 
Chiron, S., Fernandez-Alba, A.R., Rodriguez, A., Garcia-Calvo, E., 2000. Pesticide chemical oxidation: state of the art. Water Research 34366-377.

Chopra, I., Roberts, M., 2001. Tetracycline antibiotics: Mode of action, Applications, Molecular Biology and Epidemiology of Bacterial resistance. Microbiology and Molecular Biology Reviews 65, 232-233.

Costanzo, S.D., Murby, J., Bates, J., 2005. Ecosystem response to antibiotics entering the aquatic environment. Marine Pollution Bulletin 51, 218-223.

Crane, M., Watts, C., Boucard, T., 2006. Chronic aquatic environmental risks from exposure to human pharmaceuticals. Science of the Total Environment 367, 23-41.

Delzer, G.C., McKenzie, S.W., 2003. Five-day Biochemical Oxygen Demand. in Biological indicators, Book 9. Handbooks for Water-Resources Investigations, Section A. National Field Manual for the Collection of Water-Quality Data U.S. Geological Survey Techniques of Water-Resources Investigations, USGS TWRI Book 9-A7 (Third Edition). pp 1-21.

Farré, M.J., Brosillon, S., Domènech, X., Peral, J., 2007. Evaluation of the intermediates generated during the degradation of Diuron and Linuron herbicides by the photo-Fenton reaction. Journal of Photochemistry and Photobiology A: chemistry 189, 364-373.

Fleischmann, M., Korinek, K., Pletcher, D., 1971. The oxidation of organic compounds at a nickel anode in alkaline solution. Journal of Electroanalytical Chemistry and Interfacial Electrochemistry 31, 39-49.

Floner, D., Geneste, F., 2007. Homogenous coating of graphite felt by nickel electrodeposition to achieve light nickel felts with high surface area. Electrochemistry Communications 9, 2271-2275. 
Floner, D., Moinet, C., 2004. Dispositif pour métalliser un feutre graphitique, procédé mis en œuvre par ce dispositif, feutre graphitique métallisé correspondant et utilisation d'un tel feutre graphitique métallisé. in Patent FR 0213034

Fontmorin, J.M., Huguet, S., Fourcade, F., Floner, D., Geneste, F., Amrane, A., 2012. Electrochemical oxidation of 2,4-D: analysis of byproducts and Improvement of the biodegradability. Chemical Engineering Journal 195-196, 208-217.

Fontmorin, J.M., Huguet, S., Fourcade, F., Geneste, F., Floner, D., Amrane, A., 2013. Coupling of an electrochemical process with a biological treatment for the removal of 2,4Dichlorophenoxyacetic acid. Biochemical Engineering Journal 70, 17-22.

Hahn, F., Floner, D., Beden, B., Lamy, C., 1987. In situ investigation of the behavior of a nickel electrode in alkaline solution by UV visible and IR reflectance spectroscopies. Electrochimica Acta 32, 1631-1636.

Hirsch, R., Ternes, T.A., Haberer, K., Kratz, K.L., 1999. Occurrence of antibiotics in the aquatic environment. Science of the Total Environment 225, 109-118.

Kraft, A., 2007. Doped diamond: A compact review on a new, versatile electrode material. International Journal of Electrochemical Science 2, 355-385.

Kummerer, K., 2004. Resistance in the environment. Journal of Antimicrobial Chemotherapy 54, 311-320.

Maroga Mboula, V., Hequet, V., Gru, Y., Colin, R., Andres, Y., 2012. Assessment of the efficiency of photocatalysis on tetracycline biodegradation. Journal of Hazardous Materials 209-210, 355-364. 
Martel, A., Mahdavi, B., Lessard, J., Brossard, L., Ménard, H., 1997. Electrocatalytic hydrogenation of phenon on various electrode materials. Canadian Journal of Chemistry $75,1862-1867$.

Masawat, P., Slater, J.M., 2007. The determination of tetracycline residues in food using a disposable screen-printed gold electrode (SPGE). Sensors Actuators B 124, 127-132.

Merle, R., Hajek, P., Käsbohrer, A., Hegger-Gravenhorst, C., Mollenhauer, Y., Robanus, M., Ungemanch, F.R., Kreienbrock, L., 2012. Monitoring of antibiotic consumption in livestock: a German feasibility study. Preventive Veterinary Medicine 104, 34-43.

Mohajerani, M., Mehrvar, M., Ein-Mozaffari, F., 2009. An overview of the integration of advanced oxidation technologies and other processes for water and wastewater treatment. International Journal of Engineering 3, 120-146.

Moinet, C., 1994. Electrosynthèse organique en continu. Méthodes directes et indirectes. Le Journal de Physique IV 4, 175-184.

Oller, I., Malato, S., Sanchez-Perez, J.A., Maldonado, M.I., Gasso, R., 2007. Detoxification of wastewater containing five common pesticides by solar AOPs-biological coupled system. Catalysis Today 129, 69--78.

Oppenländer, T., 2003. Photochemical purification of water and air. Advanced oxidation processes (AOPs): Principles, reaction mechanisms, reactor concepts., Wiley-VCH, New York

Prado, N., Montéléon, C., Ochoa, J., Amrane, A., 2010. Evaluation of the toxicity of veterinary antibiotics on activated sludge using a modified Sturm-test - Application to tetracycline and tylosin. Journal of Chemical Technology and Biotechnology 85, 471-477. 
Prado, N., Ochoa, J., Amrane, A., 2009. Biodegradation and biosorption of tetracycline and tylosine antibiotics in activated sludge system. Process Biochemistry 44, 1302-1306.

Pulgarin, C., Invernizzi, M., Parra, S., Sarria, V., Polania, R., Péringer, P., 1999. Strategy for the coupling of photochemical and biological flow reactors useful in mineralization of biorecalcitrant industrial pollutants. Catalysis today 54,, 341-352.

Reyes, C., Fernandez, J., Freer, J., Mondaca, M.A., Zaror, C., Malato, S., Mansilla, H.D., 2006. Degradation and inactivation of tetracycline by $\mathrm{TiO}_{2}$ photocatalysis. Journal of Photochemistry and Photobiology A: chemistry 184, 141-146.

Sarria, V., Kenfack, S., Guillod, O., Pulgarin, C., 2003. An innovative coupled solar-biological system at field pilot scale for the treatment of biorecalcitrant pollutants. Journal of Photochemistry and Photobiology A: chemistry 159, 89-99.

Sarria, V., Parra, S., Adler, N., Peringer, P., Benitez, N., Pulgarin, C., 2002. Recent developments in the coupling of photoassisted and aerobic biological processes for the treatment of biorecalcitrant compounds. Catalysis Today 76, 301-315.

Scott, J.P., Ollis, D.F., 1995. Integration of chemical and biological processes for water treatment: Review and recommendations. Environmental Progress 14, 88-103.

Scott, J.P., Ollis, D.F., 1997. Integration of chemical and biological oxidation processes for water treatment: II. Recent illustrations and experiences. Journal of Advanced Oxidation Technology 2, 374-381.

Vedenyapina, M.D., Eremicheva, Y.N., Vedenyapin, A.A., 2008. Electrochemical degradation of tetracycline. Russian Journal of Applied Chemistry 81, 765-767. 
Vértes, G., Horányi, G., 1974. Some problems of the kinetics of the oxidation of organic compounds at oxide-covered nickel electrodes. Journal of Electroanalytical Chemistry and Interfacial Electrochemistry 52, 47-53.

Vilar, M., Oliveira, J.L., Navarro, M., 2010. Investigation of the hydrogenation reactivity of some organic substrates using an electrocatalytic method. Applied Catalysis A: General $372,1-7$.

Walsh, F., Mills, G., 1993. Electrochemical techniques for a cleaner environment. Chemical Industry 8, 576-580.

Weichgrebe, D., Danilova, E., Rosenwinkel, K.H., Vedenjapin, A.A., Baturova, M., 2004. Electrochemical oxidation of drug residues in water by the example of tetracycline, gentamicin and aspirin. Water Science and Technology 49, 201-206.

Yahiat, S., Elandaloussi, K., Fourcade, F., Brosillon, S., Amrane, A., 2012. Relevance of photocatalysis prior to biological treatment of organic pollutants - Selection criteria. Chemical Engineering and Technology 35, 238-246.

Yahiat, S., Fourcade, F., Brosillon, S., Amrane, A., 2011. Removal of antibiotics by an integrated process coupling photocatalysis and biological treatment - Case of tetracycline and tylosine. International Biodeterioration and Biodegradation 65, 997-1003.

Zhang, H., Liu, F., Wu, X., Zhang, J., Zhang, D., 2009. Degradation of tetracycline in aqueous medium by electrochemical method. Asia-Pacific Journal of Chemical Engineering 4, $568-573$. 


\section{Tables}

\section{Table 1}

Effect of the oxidation potential on tetracycline degradation on nickel / carbon felt electrode. (Flow rate: $1 \mathrm{ml} \mathrm{min}^{-1}$ )

\begin{tabular}{lllllllllll}
\hline \multicolumn{3}{l}{ Reduction } & \multicolumn{8}{c}{ Oxidation } \\
\hline $\mathrm{E}(\mathrm{V})$ & -0.6 & -0.7 & -0.8 & -0.9 & -1.0 & 0.3 & 0.4 & 0.5 & 0.7 & 0.8 \\
& & & & & & & & & \\
\hline Removal & 36.47 & 49.98 & 51.05 & 56.95 & 82.50 & 5.50 & 96.43 & 99.10 & 100 & 100 \\
yield (\%) & & & & & & & & & & \\
\hline
\end{tabular}

\section{Table 2}

Tetracycline degradation by oxidation and mineralization yields.

\begin{tabular}{llllll}
\hline Flow rate $\left(\mathrm{ml} \mathrm{min}^{-1}\right)$ & 1.00 & 2.25 & 3.50 & 4.75 & 6.00 \\
\hline$\left([\mathrm{TC}]_{0}-[\mathrm{TC}]\right) /[\mathrm{TC}]_{0}(\%)$ & 100 & 100 & 100 & 100 & 100 \\
\hline${\text { (TOC } 0-\mathrm{TOC}) / \mathrm{TOC}_{0}(\%)}^{3} 31.0 \pm 2.5$ & $22.4 \pm 2.5$ & $14.83 \pm 2.5$ & $13.3 \pm 1.4$ & $13.3 \pm 1.4$
\end{tabular}

\section{Table 3}

Oxidation, mineralization, and biodegradability of tetracycline electrolyzed on nickel / carbon felt electrode in oxidation in alkaline medium $(\mathrm{NaOH} 0.1 \mathrm{M})$ at $0.7 \mathrm{~V}$.

\begin{tabular}{lllll}
\hline \multicolumn{5}{l}{ Flow rate $\left(\mathrm{mL} \mathrm{min}^{-1}\right)$} \\
\hline & Untreated TC & 1 & 3 & 5 \\
\hline TOC $\left(\mathrm{mg} \mathrm{l}^{-1}\right)$ & $55.5 \pm 0.9$ & $36.9 \pm 0.9$ & $50.1 \pm 0.7$ & $46.8 \pm 0.4$ \\
& & & & $111 \pm 4$ \\
\hline $\mathrm{COD} \mathrm{mg} \mathrm{O} 1^{-1}$ & $145 \pm 1$ & $117 \pm 4$ & $99 \pm 5$ & $2.37 \pm 0.13$ \\
\hline $\mathrm{COD} / \mathrm{TOC}$ & $2.61 \pm 0.05$ & $3.17 \pm 0.17$ & $1.98 \pm 0.11$ & \\
\hline
\end{tabular}




\begin{tabular}{lcccc}
\hline AOS & $0.08 \pm 0.01$ & $-0.76 \pm 0.04$ & $1.04 \pm 0.09$ & $0.44 \pm 0.03$ \\
\hline BOD $_{5} \mathrm{mg} \mathrm{O}_{2} \mathrm{l}^{-1}$ & $0 \pm 0$ & $52.5 \pm 2.5$ & $48 \pm 4$ & $31 \pm 3$ \\
\hline BOD $_{5} / \mathrm{COD}$ & $0 \pm 0$ & $0.45 \pm 0.01$ & $0.48 \pm 0.02$ & $0.28 \pm 0.02$ \\
\hline
\end{tabular}

Figure captions

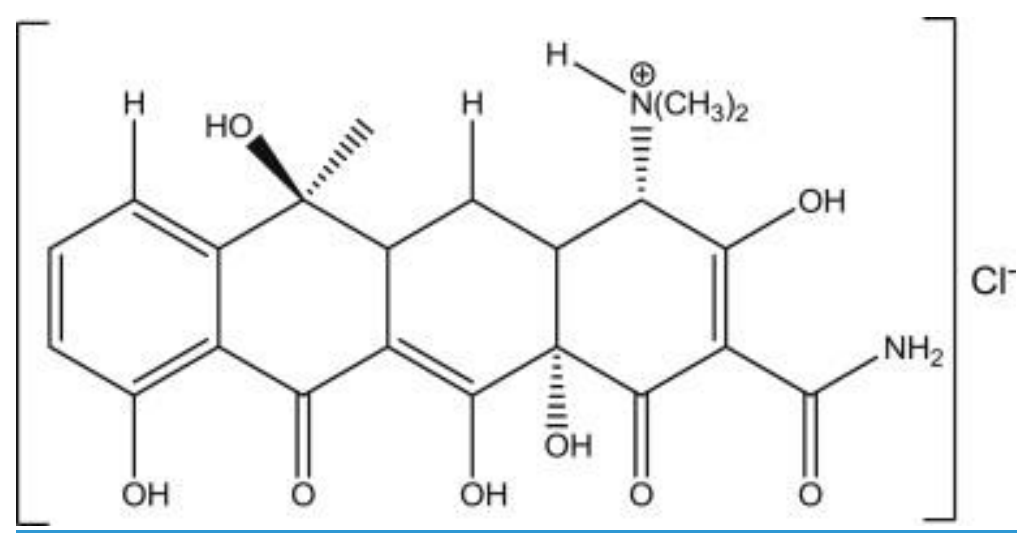

Fig. 1. Chemical structure of hydrochlorated tetracycline. 
(a)

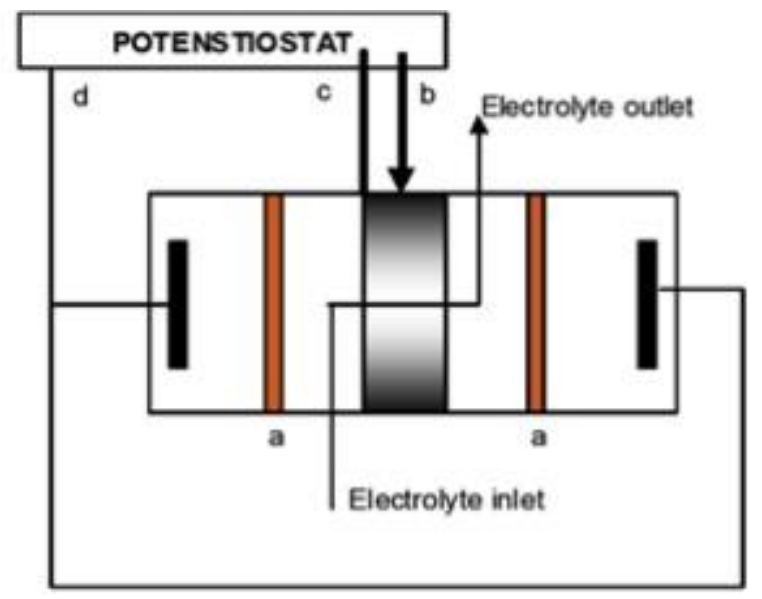

(b)

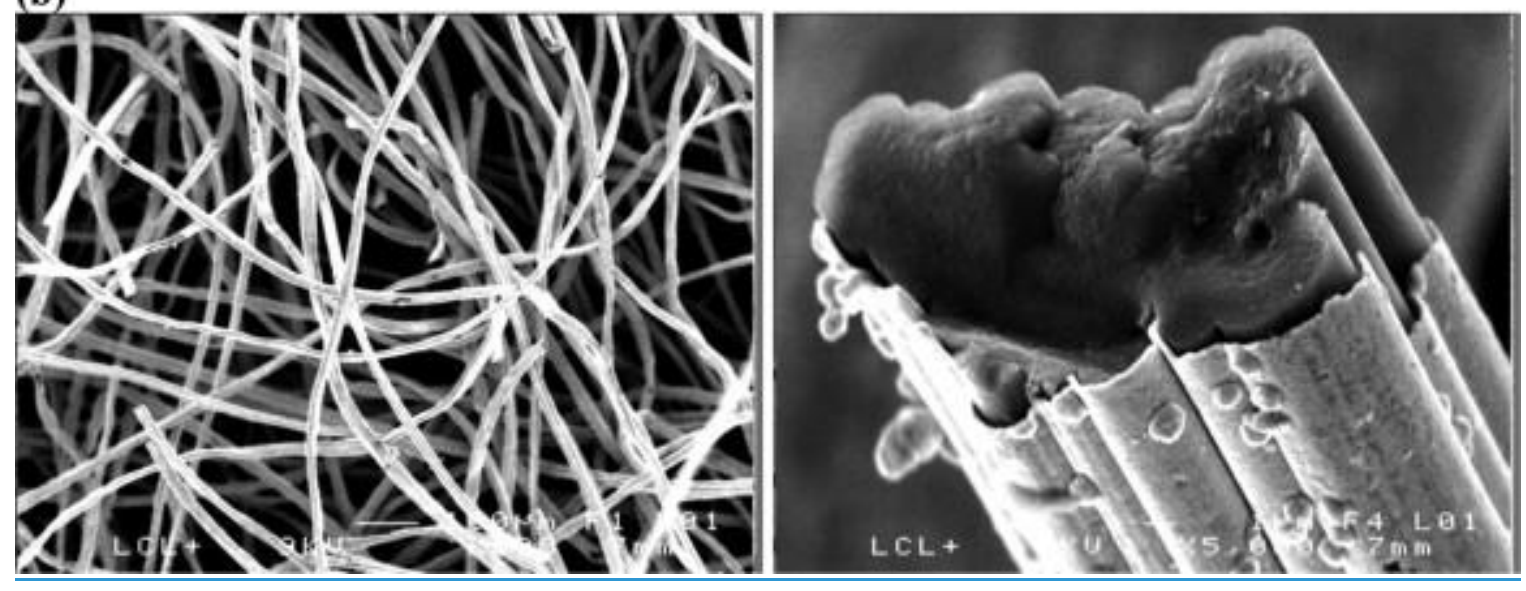

Fig. 2. (a) Schematic diagram of the percolation cell: a: cationic membranes; b: saturated

calomel electrode (SCE); c: working electrode (disc of graphite covered with nickel felt: $10 \mathrm{~mm}$ diameter, $10 \mathrm{~mm}$ thickness); d: auxiliary counter electrodes. (b) SEM images of a nickel coating graphite felt (thickness $3 \mathrm{~mm}$ ). 

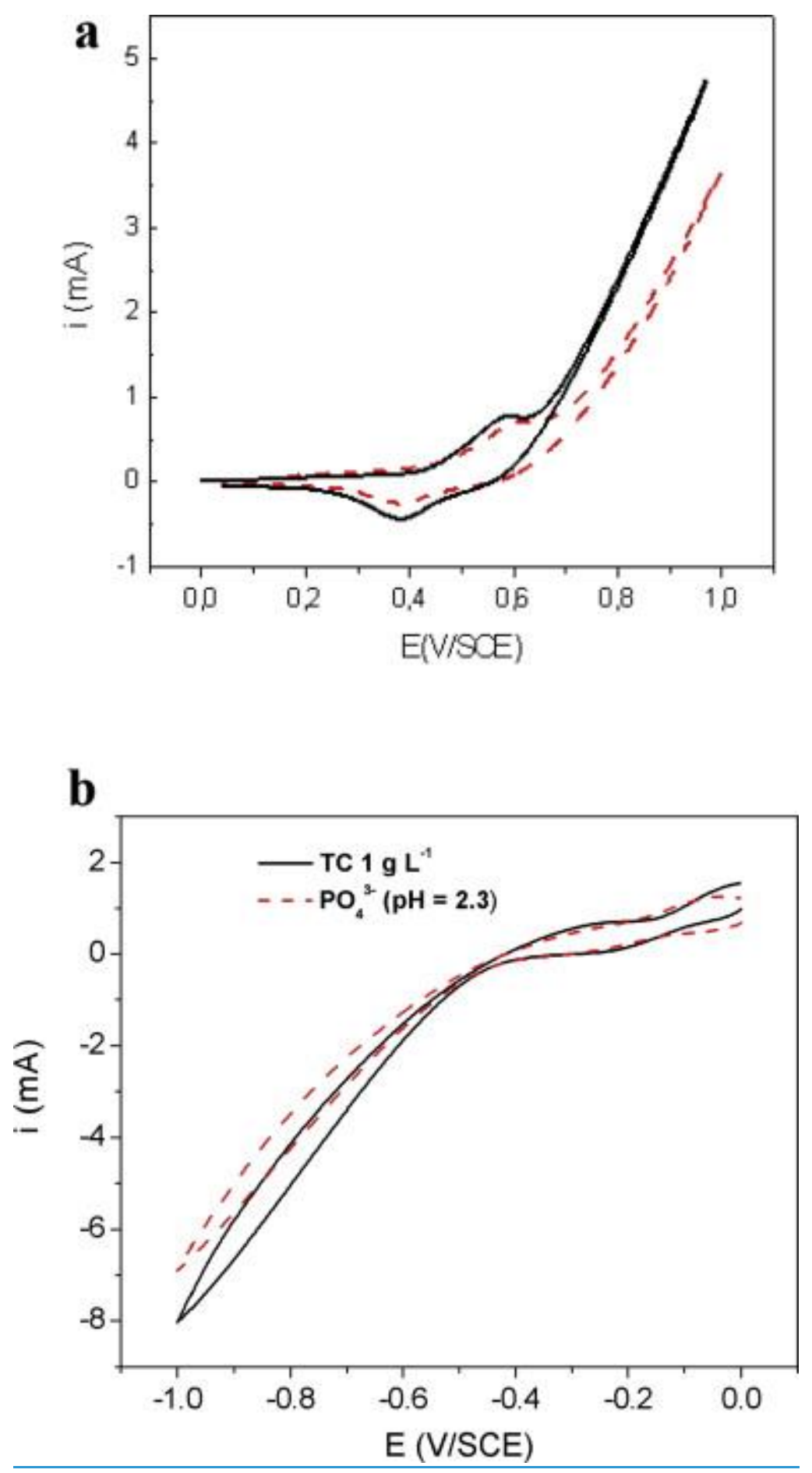

Fig. 3. Current-potential curve obtained in oxidation by cyclic voltammetry $\left(100 \mathrm{mVs}^{-1}\right)$ with a nickel electrode $\left(\mathrm{S}=20 \mathrm{~mm}^{2}\right)$, under nitrogen atmosphere and $\mathrm{T}=298 \mathrm{~K}, 0.1 \mathrm{~g} \mathrm{l}^{-1} \mathrm{TC}$ in $0.1 \mathrm{~mol}$ $\mathrm{l}^{-1} \mathrm{NaOH}$ (a) and $1 \mathrm{~g} \mathrm{l}^{-1} \mathrm{TC}$ in $0.1 \mathrm{~mol} \mathrm{l}^{-1}$ phosphate buffer (b). Current-potential curve in the absence (red) and in the presence of TC (black line). 


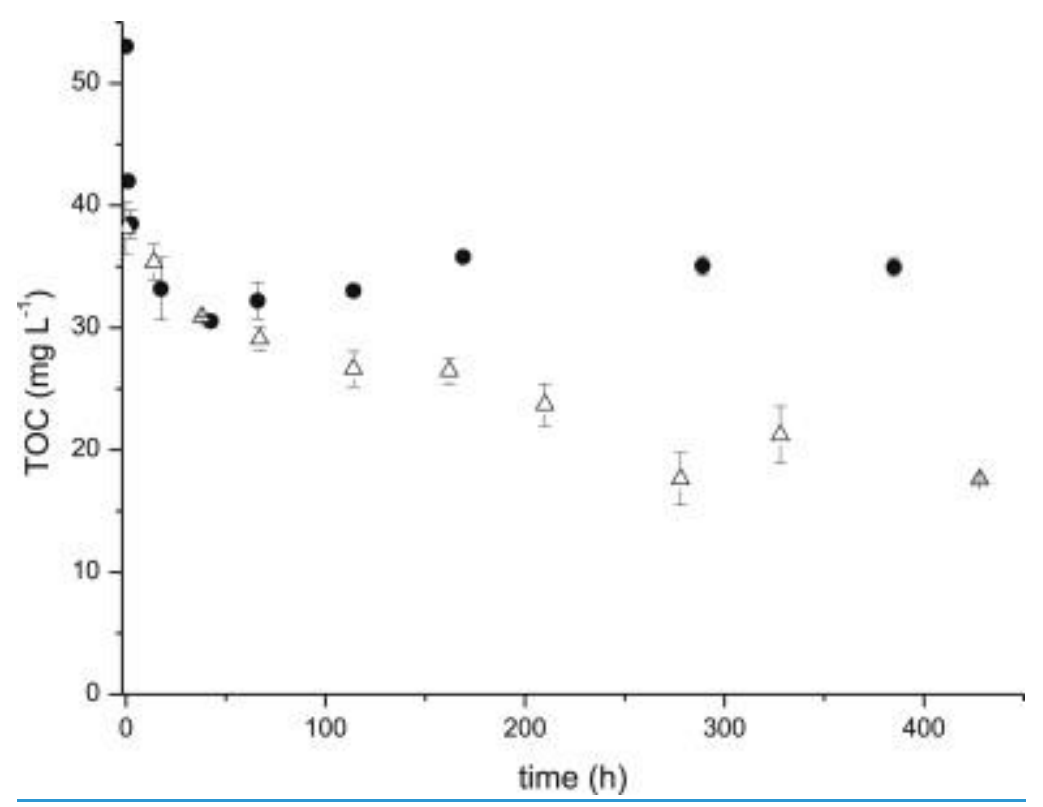

Fig. 4. Time-courses of the total organic carbon concentration during activated sludge culture on tetracycline $\left(100 \mathrm{mg}^{-1}\right)$ non-pretreated $(\bullet)$ and after oxidation in a single pass through the percolation cell at a flow rate of $3 \mathrm{ml} \mathrm{min}^{-1}$ at $0.7 \mathrm{~V}$ in $0.1 \mathrm{~mol} \mathrm{l}^{-1} \mathrm{NaOH}(\Delta)$. 